Int. J. Dev. Biol. 52: 229-236 (2008)

doi: $10.1387 / \mathrm{ijdb} .072340 \mathrm{ar}$

\title{
Embryonic development of the proepicardium and coronary vessels
}

\author{
ANNA RATAJSKA ${ }^{1, *}$, ELZBIETA CZARNOWSKA ${ }^{2}$ and BOGDAN CISZEK ${ }^{3}$ \\ ${ }^{1}$ Department of Pathological Anatomy, Medical University of Warsaw, ${ }^{2}$ Department of Pathology, Childrens' Memorial Health Institute \\ and ${ }^{3}$ Department of Anatomy, Medical University of Warsaw, Poland
}

\begin{abstract}
In the last few years, an increasing interest in progenitor cells has been noted. These cells are a source of undifferentiated elements from which cellular components of tissues and organs develop. Such progenitor tissue delivering stem cells for cardiac development is the proepicardium. The proepicardium is a transient organ which occurs near the venous pole of the embryonic heart and protrudes to the pericardial cavity. The proepicardium is a source of the epicardial epithelium delivering cellular components of vascular wall and interstitial tissue fibroblasts. It contributes partially to a fibrous tissue skeleton of the heart. Epicardial derived cells play also an inductive role in differentiation of cardiac myocytes into conductive tissue of the heart. Coronary vessel formation proceeds by vasculogenesis and angiogenesis. The first tubules are formed from blood islands which subsequently coalesce forming the primitive vascular plexus. Coronary arteries are formed by directional growth of vascular protrusions towards the aorta and establishing contact with the aortic wall. The coronary vascular wall matures by attaching smooth muscle cell precursors and fibroblast precursors to the endothelial cell wall. The cells of tunica media differentiate subsequently into vascular smooth muscle by acquiring specific contractile and cytoskeletal markers of smooth muscle cells in a proximal - distal direction. The coronary artery wall matures first before cardiac veins. Maturity of the vessel wall is demonstrated by the specific shape of the internal surface of the vascular wall.
\end{abstract}

KEY WORDS: epicardium, hematopoiesis, vasculogenesis, coronary vessel development, mesenchymal cell

\section{Introduction}

The tissues and organs of multicellular organisms develop from the pool of undifferentiated progenitor cells. The example of such a pool of progenitor cells is vertebrate proepicardium, which contains cells for the development of the heart. The proepicardium is a transient organ which is located near the venous pole of the embryonic heart and protrudes to the pericardial cavity (Virágh et al., 1993). The current data on coronary vessel development indicate that the proepicardium is a source of the epicardial epithelium (Männer et al., 2001), which participates in the formation of the vascular wall containing endothelial cells, smooth muscle cells and fibroblasts (Männer et al., 2001). The proepicardium is also a source of cells forming connective tissue of the heart valves and modulating formation of the heart skeleton (Winter, Gittenberger-de Groot 2007). The proepicardium is described as the "organ" because it is a source of a heterogenous population of progenitor cells, which participate in the development of various structures of the heart. These cells participate in such processes as vasculogenesis, angiogenesis, morphogenesis and remodeling of extracellular matrix.

\section{Formation of the proepicardium}

The primordium of the proepicardium is found on the surface of the septum transversum in mammals, and on the surface of the sinus venosus near the embryonic liver in birds. The proepicardium primordium forms as the multicellular protrusion of the pericardial serosa covering both horns of the sinus venosus (in mammals) or the right sinus horn (in birds) (Männer et al., 2001, Schulte et al., 2007). These protrusions contain hyaluronic acid and a small amount of fibronectin (Kálmán et al., 1995; Männer et al., 2001). At this stage of development, in mammals, the embryonic liver grows into the septum transversum. In birds, which lack the

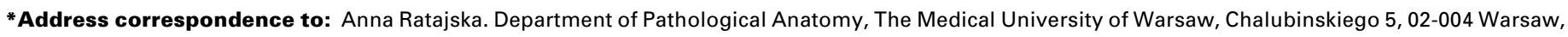
Poland. Fax: +48-(22)-629-9892. e-mail: arataj@ib.amwaw.edu.pl

Published online: 14 February 2008
} 


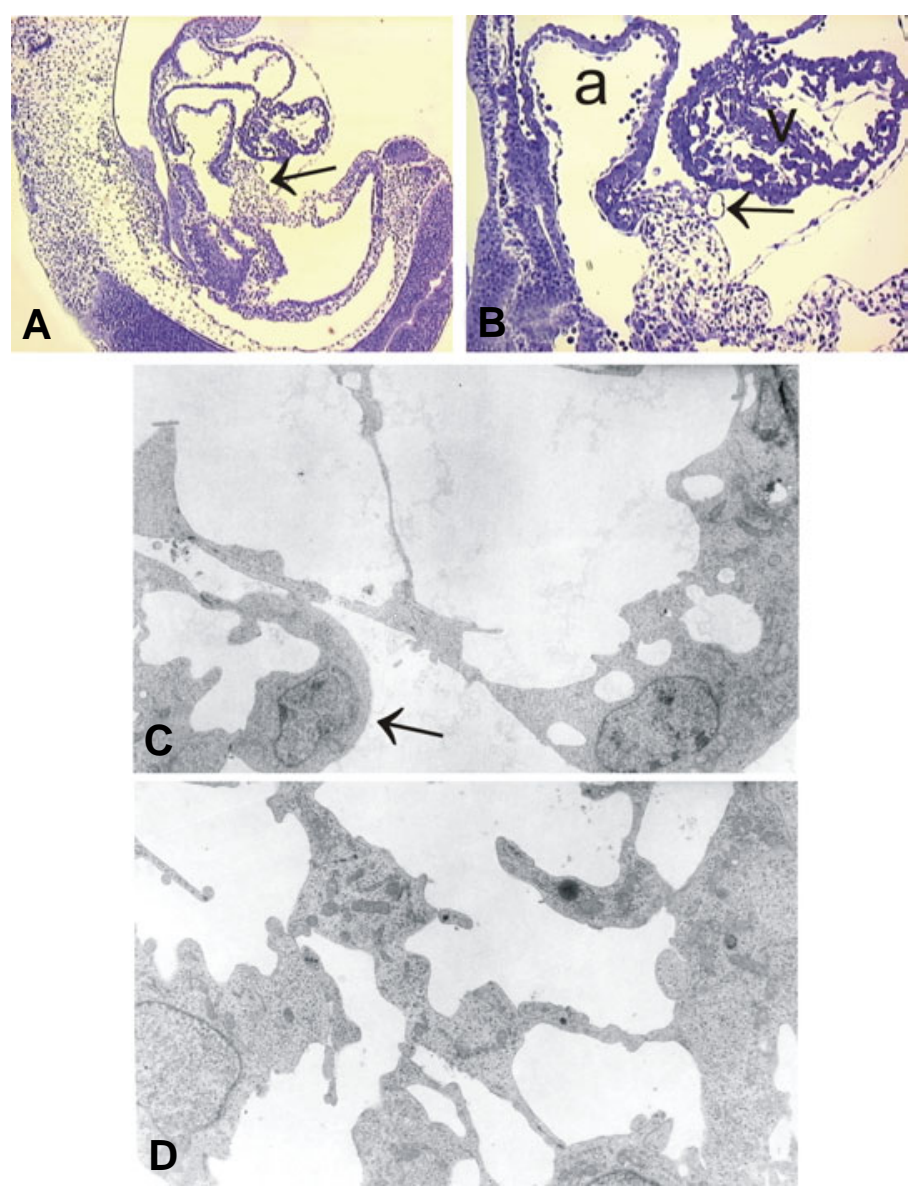

Fig. 1. The proepicardium of a mouse embryo at stage 9.5 dpc. (A) $A$ sagittal section of the embryo showing the location and the structure of the proepicardium (arrow), mag. 50x. (B) The proepicardium releasing a vesicle (arrow), mag. 90x. (C) Transmission electron microscopy image of the proepicardial surface with epithelial-like cells (arrow), mag. 2600x. (D) Transmission electron microscopy image of the proepicardium with loosely arranged mesenchymal cells; mag. 3300x; a, atrium; v, ventricle.

diaphragm and in which the septum transversum does not develop, the proepicardium forms near the embryonic liver. Thus, the protrusion forms in the pericardial cavity, near the septum transversum (in mammals) or fetal liver (in birds). It resembles cauliflower (in birds) and grapes (in mammals) (Ho and Shimada 1978; Virágh, Challice 1981). These protrusions give rise to the proepicardium. In the next step of proepicardium development these protrusions grow within the pericardial cavity (Fig. 1A). In birds such as quail or chicken the proepicardium reaches about $200 \mu \mathrm{m}$ in diameter, in mice - about 60-80 $\mu \mathrm{m}$ and is correspondingly larger in human. It reaches its maximum diameter at the 45 week of the prenatal life in human, at $9.5 \mathrm{dpc}$ in mice and at $\mathrm{HH} 15-17$ in birds (Hamburger and Hamilton 1951).

Polish scientist Kurkiewicz was the first who described the proepicardial protrusions (he called them villi), and suggested that they give rise to the epicardium (Kurkiewicz 1909). The proepicardium is covered with embryonic epithelial cells while the core of proepicardium constists of undifferentiated mesenchymal cells, loosely arranged and connected by intercellular junctions (Fig. 1 B,C). Further development of the proepicardium after it reaches its maximum size differs in mammals and in birds but in both cases, proepicardium differentiates into the epicardium (Virágh, Challice 1981; Hiruma, Hirakow 1989).

\section{Immunohistochemical and genetic markers of the proepicardium}

Early proepicardium does not express any markers of differentiated endothelial cells or their precursors such as angioblast (CD34, PECAM-1, VEGFR1, VEGFR2), fibroblast, hematopoietic cells (CD45, CD34), smooth muscle cells (alpha-actin) or other markers (Fig. 2). Endothelial cells are detected in the proepicardium in later stages of development when the proepicardium reaches the heart surface and attaches to it (Kattan et al., 2004; Guadix et al., 2006).

On the other hand the proepicardium contains the transcription factor of Wilm's tumor (WT-1) supressor gene, retinaldehyde dehydrogenase2 (RALDH2) (Pérez-Pomares et al., 2002b), and Tbx (Hatcher etal., 2004) and Cfcgene products (Schlueter et al., 2006). Mutant mice for WT-1 display abnormalities in the epicardium formation with a reduced number of subepicardial mesenchymal cells (Moore et al., 1999). Normal development of the proepicardium requires expression of BMP factor (Schlueter et al., 2006) and GATA4 transcription factor (Watt et al., 2004).

\section{Formation of the epicardium}

In embryonic stages of $\mathrm{HH} 14$ and $\mathrm{HH} 17$ in birds (and at 9-10 $\mathrm{dpc}$ in mice) through further bending of the head region of the embryo and concomitant heart looping the dorsal surface of the heart loop approaches the ventral wall of the sinus venosus. In birds, the growing protrusions of the proepicardium approach the dorsal surface of the heart and attach to it. This forms a bridge in the pericardial cavity, between the ventral surface of the sinus venosus and dorsal wall of the heart (Männer 1993). In birds this bridge is composed of extracellular matrix (ECM) including heparan sulfate and fibronectin (Ho, Shimada 1978; Männer 1992; Männer 1993; Virágh et al., 1993; Männer 1999; Nahirney et al., 2003). The bridge was also observed in mammals (Nesbitt et al., 2006) and its composition is similar. Looping heart is covered by cells deriving from the proepicardium, which form a simple squamous epithelium i.e. the epicardium. Initially these cells adhere to the dorsal surface of the heart. Then cells of the epicardium proliferate and spread on the heart surface (Hiruma, Hirakow 1989).

In mammals, formation of the epicardium from the proepicardium, occurs via a release of free-floating vesicles into the pericardial cavity. These vesicles are released from the tip of the proepicardium (Virágh, Challice 1981; Kuhn, Liebherr 1988; Van den Eijnde et al., 1995). In mice, the highest number of freefloating vesicles in the pericardial cavity occurs at 9.5-10 dpc. These vesicles reach also the dorsal surface of the heart, attach to it, and subsequently flatten and spread on the surface of the "naked" heart. Expansion of the epicardium occurs by proliferation of proepicardial and mesothelial cells. (Fig. 3). These cells express cytokeratins, which are the marker of epithelial cells (Vrancken Peeters et al., 1995). There is a distinct spatialtemporal pattern of the spreading of the mesothelial cells on the surface of the heart. The apical surfaces of the proepicardial clusters bleb off from the proepicardium, attach to the dorsal wall 
of the atrioventricular sulcus and become the epicardial mesothelium. Subsequently the epicardium covers almost the whole dorsal surface of the ventricle moving towards the atrium and bulbus cordis, with a delay in the covering of the ventral surface. Beginning from the dorsal surface of the heart, the epithelial cells form the rings in the atrioventricular and ventriculo-bulbar sulcuses, subsequently cells spread to the right and to the left around the looping heart on the ventricular surface (the heart is $U$-shaped at this stage of development). Then, cells spread cranially and caudally reaching the outflow tract and atria (the shape of the heart resembles an "S") (Hiruma, Hirakow 1989; Vrancken Peeters et al., 1995). The front line of the spreading epicardial cells covering the looping heart has a semilunar shape. The cells expand on the heart surface radially from the atrioventricular sulcus. In mice, by the end of $11 \mathrm{dpc}$, the heart is entirely covered by the epicardium. This corresponds to the stage $\mathrm{HH} 26$ in birds. In chicken, covering the heart with the epicardium takes 2 days.

All proepicardial cells transform into the cells of epicardium. The proepicardium disappears by the end of the 5 th week of human development (in mice by $10.5-11 \mathrm{dpc}$ ). The limited release of cells is observed in a group of mesothelial cells from the dorsal surface of the pericardial cavity in several animal species (Männer et al., 2001). We noticed such cell release in the pericardium of mouse embryos (Fig. 4).

\section{The epithelial-mesenchymal transformation of epicar- dial cells}

In further stages of development the epicardium forms cellular components of the subepicardium. Subepicardium synthesizes extra cellular matrix built from glycosaminoglycans, collagen, elastin, and fibronectin. This occurs through the invagination of the subpopulation of epicardial cells under the surface of the epicardium. The invaginating cells lose their epithelial character and transform into undifferentiated mesenchymal cells (Dettman et al., 1998; Pérez-Pomares et al., 1998). This phenomenon is called the epithelial-mesenchymal transformation (EMT). It is accompanied by expression of the Slug and Snail transcription factors, whose presence are necessary for this process (Carmona et al., 2000; Cano et al., 2000). Other growth factors like TGF- $\beta 1$ and -2 also stimulate this process through their constitutive
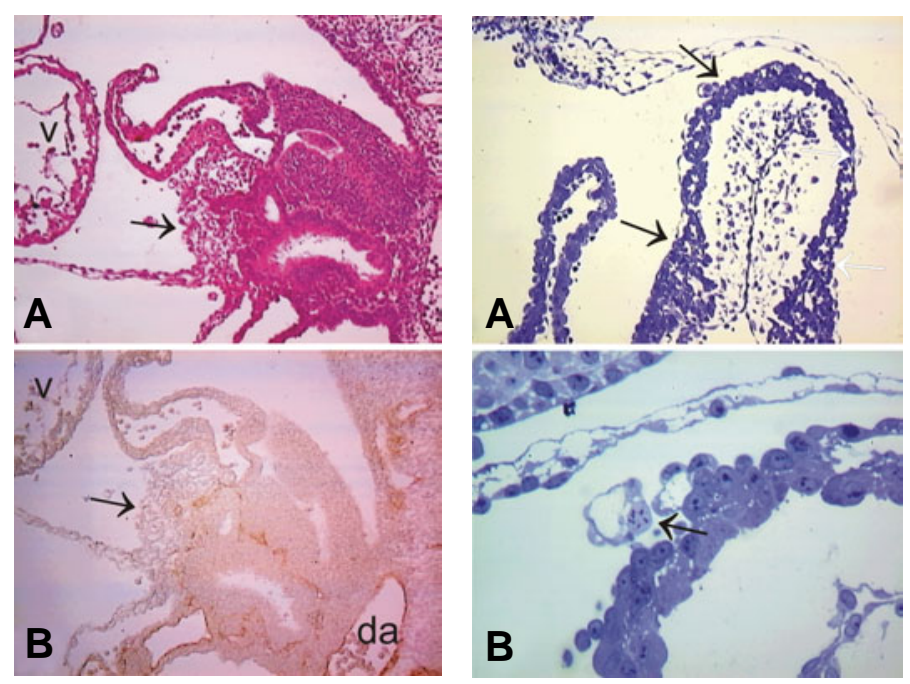

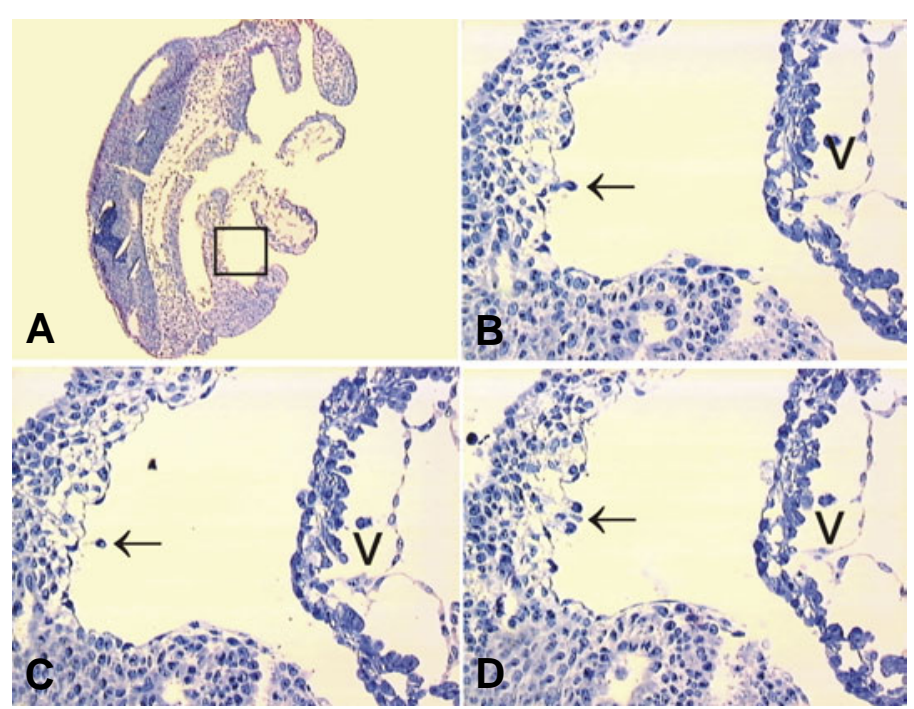

Fig. 4. Mouse embryo at the stage of $\mathbf{9 . 5}$ dpc. The dorsal surface of the peritoneal-pericardial cavity with released epithelial cells, which form vesicle-like structures similar to those observed in the proepicardium. (A) The area in the rectangle is enlarged in $(B, C, D)$. (B,C,D) Serial sections; $\checkmark$, ventricle; magnifications: (A) 60x, (B-D) 220x.

receptor- ALK2 (Olivey et al., 2006). Mesenchymal cells are a source of extracellular matrix. Erytrocytes and angioblasts are found in newly formed subepicardium (Virágh etal., 1993; Ratajska etal., 2006, Tomanek et al., 2006a). Erythrocytes are surrounded by angioblasts forming the primitive vascular vesicles (Fig. 5).

Similar epithelial-mesenchymal transformation occurs within the endocardial cushion tissue of the heart; here, the endocardial endothelial cells lose their epithelial character and transform into the mesenchymal cells of the cushion tissue (Markwald et al., 1977).

The mesenchymal cells which derive from the epicardium (epicardial-derived mesenchymal cells - EPDC) build a layer of connective tissue, which is the thickest in the atrioventricular and interventricular sulcuses. This connective tissue will form the epicardium, which will be covered with epithelial cells and filled with fibroblasts and extracellular matrix built from collagen, glycosaminoglycans, elastic and collagen fibers. Subepicardial space is occupied by primitive vascular vesicles, which are not yet connected to the systemic circulation (Kálmán et al., 1995).

The routs of migration of mesenchymal cells derived from the epicardium (and earlier from the proepicardium) are known from the analysis of interspecies chimeras, in which the quail

Fig. 2 (Left). The sagittal section of the proepicardium of mouse embryo at the stage of 9.5 dpc. (A) A histological section of the proepicardium (arrow) stained with hematoxylin-eosin; numerous vesicles released to the pericardial cavity are visible. (B) Section stained with antiCD34 antibodies; CD34 positive cells are located in the dorsal aorta and at the base of the proepicardium; $v$, ventricle; da, dorsal aorta. Magnification: $200 x$

Fig. 3 (Right). The heart of mouse stage of $10 \mathrm{dpc}$ embryo partially covered with the epicardium. (A) The area covered with the epicardium is located between arrows; mag. 200x. (B) Proliferating epicardial cell (arrow), mag. 380x. 
proepicardium was inserted into the chicken pericardial cavity (Gittenberger-de Groot et al., 1998). The presence of quail specific nuclear marker allowed tracking the migration of quail cells in the chimeric chicken embryo. In addition, the retroviral tagging of the proepicardium with a reporter gene for $\beta$-galactosidase allowed tracking the migration of proepicardium-derived cells (Mikawa, Fishman 1992; Mikawa, Gourdie 1996).

It is not known whether there are separate populations of mesothelial cells able to differentiate into different cell types: endothelial, smooth muscle or fibroblast, or whether all EPDC are able to differentiate into all types of cells, depending on the action of specific growth factors (Dettman et al., 1998; Pérez-Pomares et al., 2002a). In vitro studies showed that the growth factors are able to induce all these transformations in certain populations of mesenchymal cells. Also the epicardial epithelium has a great capacity to differentiate into other cell types (Wessels, PérezPomares 2004). The process begins with initial dedifferentiation of flat epithelial cells into mesenchymal cells. Although the proepicardium does not have differentiated cells it has an enormous potential to differentiate into vascular cells in vivo and in vitro (Guadix et al., 2006, Pérez-Pomares et al., 2006).

Knockout mice devoid of VCAM-1 adhesive molecule do not develop the epicardium and their myocardium is very thin. A large amount of blood cells is present within the pericardial cavity of these knockout mice (Kwee et al., 1995). Photoablation experiments on chicken hearts showed that the hearts are devoid of the proepicardium and epicardium, are thin-walled and aneurysmal, have defects of coronary vasculature and develop hemo- and hydropericardium (Männer et al., 2005). This indicates that the proepicardium plays a role in maintaining the mechanical properties of the heart wall.

\section{Formation of coronary vessels}

The coronary vessels develop from the blood islands which are the aggregates of endothelial cells and erythrocytes and are not connected to the systemic circulation (Hirakow 1983; Rongish et al., 1994; Ratajska, Fiejka 1999). The blood islands coalesce to form the primitive vessels. In birds, at the HH23 stage, the blood islands, erythrocytes and capillary vessels are most numerous within the subepicardial space (Hiruma, Hirakow 1989) and the vascularization of the heart is proceded by the development of the epicardial cover. In birds and mammals, the earliest vascular structures are visible within the sinus venosus and the dorsal part of the atrioventricular sulcus - which is the area of developing heart first being covered by the epicardium (Vrancken
Peeters et al., 1997b; Kattan et al., 2004).

The origin of the erythrocytes within the blood islands is another interesting issue. It has been suggested that the erthrocytes and angioblasts derive from a common precursor cells hemangioblasts (Pardanaud et al., 1989; Muñoz-Chápuli et al., 1999). Retroviral tagging of the proepicardium showed that the erythrocytes of the subepicardium derive from the proepicardial progenitor cells which differentiate into erythroblasts wthin the heart (Tomanek et al., 2006a). This appears to be consistent with the results of earlier studies showing the presence of erytroblasts within the subepicardium (Virágh 1990; Kálmán et al., 1995) and the recent study by Kattan (2004) demonstrating presence of progenitor cell markers (CD45) on erythroblast clusters within subepicardial area. Another possible source of erythrocytes within the blood islands, would be the systemic circulation from where they migrate to the heart and subsequently assemble with angioblasts (Ratajska et al., 2006).

Retroviral tagging of the proepicardium identified the sources of smooth muscle cells of the tunica media, fibroblasts of the adventitia of large vessels, and the interstitial heart fibroblasts (Mikawa and Fischman, 1992; Mikawa and Gourdie, 1996). All these cell types derive from the epicardial mesothelium by the epithelial-mesenchymal transformation (EMT) and subsequent differentiation (Dettman et al., 1998; Gittenberger-de Groot et al., 1998; Vrancken Peeters et al., 1999; Pérez-Pomares et al., 2002a; Muñoz-Chápuli et al., 2002). Mesenchymal cells are able to infiltrate myocardium reaching the subendocardial cushions (Gittenberger-de Groot etal., 1998). Depending on local availability of the growth factors such as PDGF-BB, VEGF or bFGF, the mesenchymal cells differentiate into smooth muscle cells or endothelial cells, respectively (Cox, Poole 2000; Pérez-Pomares et al., 2002a).

The studies of chicken-quail chimeras broadened our understanding of the precursors and development of the coronary vessel. There are two main theories on the origin of the vascular endothelial cells. First theory, based on experiments with quailchicken chimeras in which small pieces of quail liver were transplanted into the chicken coelom, claims that vascular endothelial cells derive from liver primordium, and the angioblasts differentiate within the subepicardium which subsequently gives rise to the primitive subepicardial vascular plexus (Poelmann et al., 2002). The second theory maintains that epicardium-derived mesenchymal cells (EPDC) are able to differentiate into vascular endothelial cells (Männer 1999; Muñoz-Chápuli et al., 2002; Pérez-Pomares et al., 2002a). The latter theory is supported by the results of the retroviral labeling of the proepicardium, and by the chicken-quail
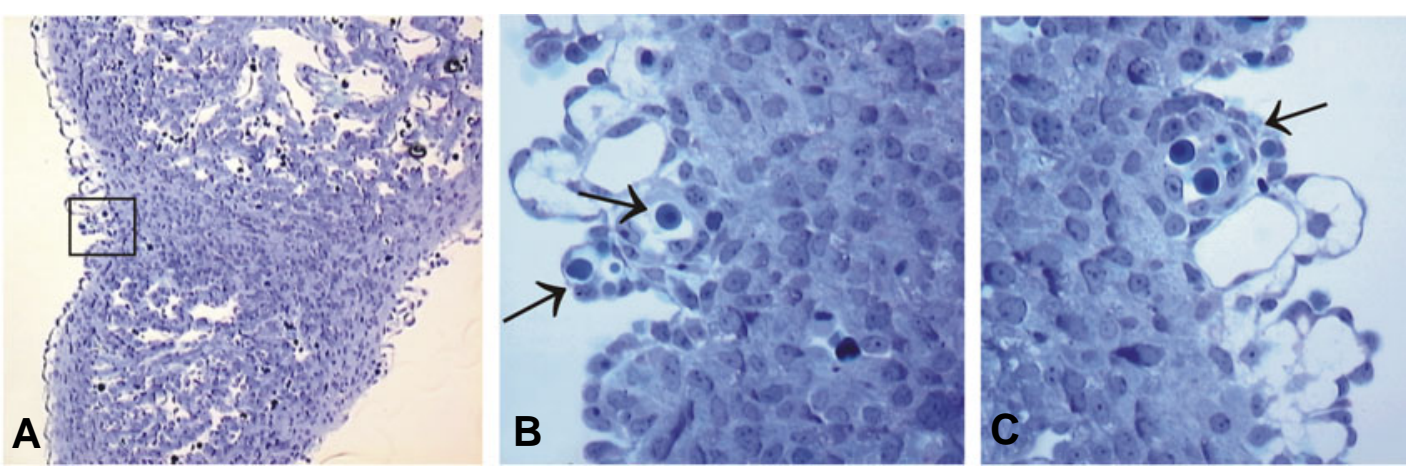

Fig. 5. The epicardium of a mouse heart at stage $13 \mathrm{dpc}$. Vascular vesicles located in the subepicardial space contain nucleated red blood cells (arrows). (A) Section of the ventricles and the interventricular sulcus; the area in the rectangle is enlarged in (B), mag. 150x. (C) Vascular vesicle in the interventricular sulcus. These vesicles are precursors of subepicardial coronary vessels. Mag. $380 x$ in $(B, C)$. 
chimera studies. Double labeling of EPDC with anti-QH1 antibodies and cytokeratin showed that both markers were present in the precursors of the coronary endothelial cells. Additional support for this theory comes from the interspecies comparison of epicardially derived cells. In dogfish (Scyliorhinus canicula) all subepicardially derived cells originate from the epicardial mesothelium. In this species subepicardial vessels arise long before the migration of extracardiac angioblasts begins (Muñoz-Chápuli et al., 1996). The experiments in rats in which avascular hearts were grafted in oculo showed that the coronary vessels in transplanted hearts develop without any vascular contribution from the host (Rongish et al., 1994). Both studies are in agreement with the idea that splanchnic angioblast differentiation occurs in situ without significant migration of vascular cell precursors (Drake et al., 1997). The idea that the angioblasts originate in situ from the splanchnic mesoderm is also supported by the studies of 5-somite stage avian embryo (Cox and Poole 2000; Poole et al., 2001).

As we mentioned previously, the blood islands are precursors of coronary vasculature. Blood islands differentiate into vascular tubes (capillaries), which appear first within the subepicardium. Capillaries grow within the subepicardium of the atrioventricular and interventricular sulcuses and coalesce forming primitive vascular network. Formation of the coronary arteries commences with directional growth of the protruding capillaries towards the sinuses of Valsalva and establishing patency with the aortic lumen (Bogers et al., 1990; Waldo et al., 1990). The protrusion of primordia of coronary arteries towards the aorta is facilitated by apoptosis of the aortic wall (Bernanke, Valkey 2002; Tomanek et al., 2006b). Connection with the aorta is established in rats on ED16 (Heinzberger 1983), at HH stage 29-35 in chicken and quail hearts (Kattan et al., 2004), and at 44-49 day in human heart (Conte, Pellegrini 1984; Hutchins et al., 1988; Mandarin-Lacerda 1990). Interestingly, there are several capillaries penetrating towards the three sinuses of Valsalva but only two (in the left and right sinuses, respectively) establish connection with the aorta (Poelmann et al., 1993). Capillary plexus spreads around the outflow tract and within the myocardium of diaphragmatic surface of the heart. Subsequently, the plexus grows on the sternal surface of the heart. The left ventricle undergoes vascularization followed by the vascularization of the right ventricle. The apex of the heart vascularizes as the last (Rychter et al., 1975, VranckenPeeters et al., 1997b, Kattan et al., 2004). Initially there is a gradient of the myocardial wall vascularization with the highest density of vessels in the subepicardium and the lowest in the subendocardium. This is consistent with the expression of VEGF and its receptor-2 (Tomanek etal., 1999a;2002; Tomanek, Zheng 2002). It is believed that the thickening of the myocardial wall (Tomanek etal., 1999b), and relative hypoxia in the subepicardium are the stimuli responsible for the rapid development of coronary vessels in the subepicardium. Multiple growth factors participate in the development and spreading of the vasculature (Ratajska et al., 1995; Tomanek et al., 1998; 2001). We do not known what signal allows the directional growth of coronary artery precursors towards the aorta. Probably the aorta is recognized by at least one signal from growth factors or from parasympathetic ganglia situated at the roots of the aorta (Hood, Rosenquist 1992). The parasympathetic ganglia which are derivative of neural crest cells (Verberne et al., 1998) are positioned closely to coronary artery ostia in chick heart (Waldo et al., 1994). This suggests that the

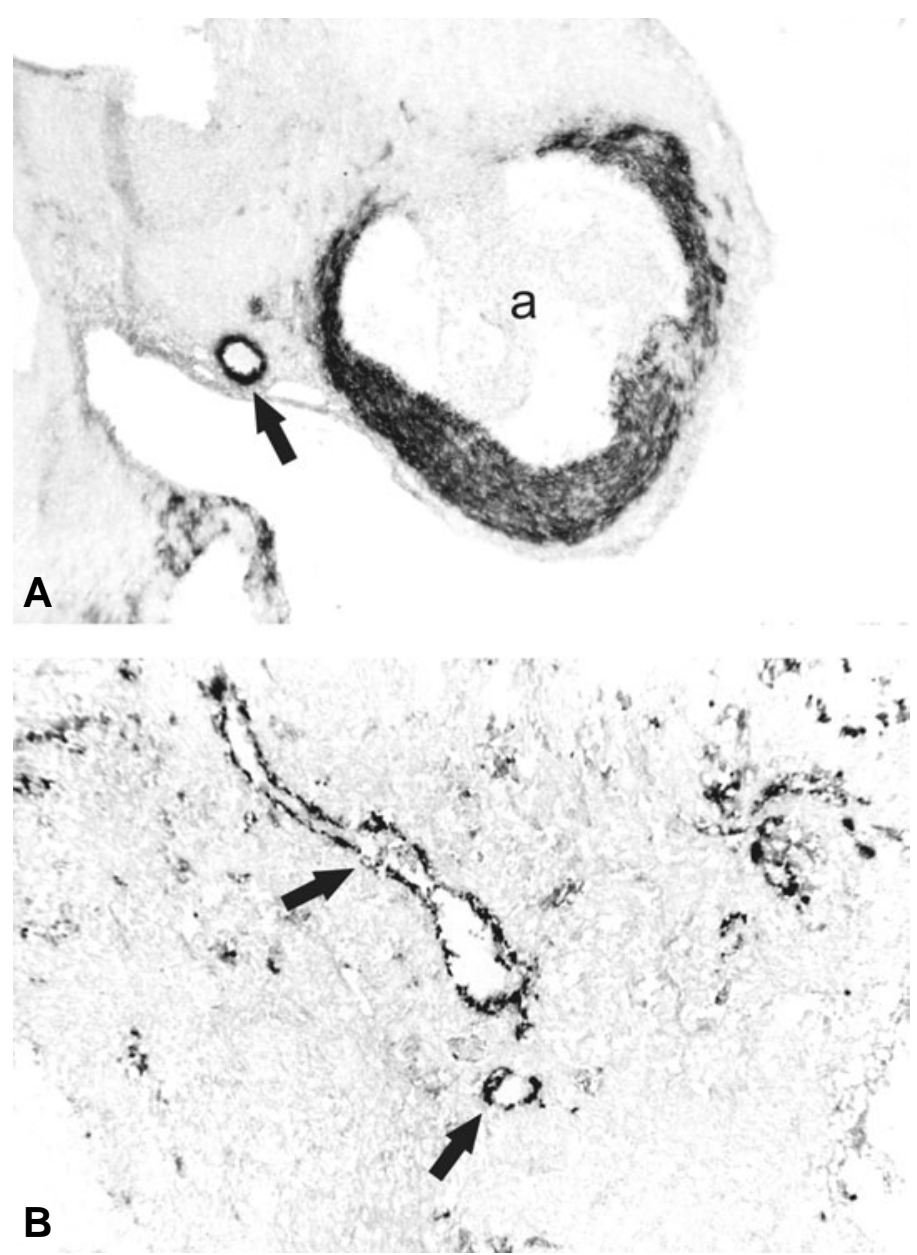

Fig. 6. Rat heart of $\mathbf{1 8} \mathbf{d p c}$ embryo. Immunostaining with anti-smooth muscle myosin antibody $(A, B)$ smooth muscle myosin is present within the proximal (A) and distal wall (B) of coronary artery.

signal(s) from the parasympathetic ganglia may contribute to the formation of coronary ostia. In cases such as Bland-WhiteGarland syndrome, this signal is imprecise allowing the primordia to grow towards the pulmonary trunk (1933). In congenital heart malformations, however, with dextroposition of the aorta relative to the pulmonary trunk, the primordial coronary arteries grow towards the aorta (Gonzáles-Iriarte et al., 2003; Ratajska et al., 2005).

Formation of the tunica media of larger coronary vessels starts at the proximal end of coronary artery by building up a layer of mesenchymal cells. These cells approach the vascular wall before the connection of coronary artery precursors with the aorta is established (Ratajska, Fiejka 1999). Further differentiation into smooth muscle cells commences when blood starts to flow within the patent coronary system (Hood, Rosenquist 1992). The differentiation into smooth muscle cells requires acquisition of certain contractile and cytoskeletal proteins, which occurs sequentially and is species-specific (Owens et al., 1995; Hungerford, Little 1999; Ratajska et al., 2001). The first is the smooth muscle alpha actin, which appears sequentially from the proximal to distal part of the coronary vessel wall (Hood, Rosenquist 1992, Ratajska et al., 2001). Subsequently, the smooth muscle myosin appears 
(Fig. 6). Concomitantly with the start of blood flow within the patent coronary system, the shear stress on endothelial cells increases stimulating a release of certain substances from the epithelial cells (Hannan et al., 1988; Joseph-Silverstein et al., 1987). These substances modulate smooth muscle cell differentiation and influence the smooth muscle cell proliferation (Sterpetti et al., 1993). An increase in shear stress within the arterial side of the coronary system and rapid blood flow in arterial wall explains why the vascular wall of arterial system differentiates earlier than the cardiac veins (Vrancken Peeters et al., 1997a). In addition, the specific shape of the internal wall of coronary vasculature of the embryonic heart can be explained by the elevated speed of blood flow within the arteries as compared to veins (Ratajska et al., 2003). The development of the coronary vessel is not restricted to the embryonic period of life and it continues postnatally. It is accomplished by remodeling of the vasculature: spreading of existing vessels by sprouting, intussusceptive growth and disappearing of the branches connecting the vessels (Tomanek 2005).

\section{The role of the epicardium in myocardial development}

Formation of the epicardium is necessary for normal development of myocardium, its "tightness", stiffness, elasticity, and for the proper vascularization of the heart wall. The heart devoid of the proepicardium (as the result of photoablation) develops malformations such as double outlet right ventricle, and deficiency of the interventricular septum in its membranous part (Männer et al., 2005). It is highly probable that EPDC takes part in the formation of the interventricular septum. It is not known however, in what way EPDC could induce the complex pathological changes of the heart such as double outlet right ventricle (Männer et al., 2005). Mice devoid of $R X R a l p h a$ gene exhibit delayed development of the epicardium. Their epicardium exhibits malformations with exuberant extracellular matrix and increased apoptosis of mesenchymal cells (Jenkins et al., 2005). These mice have lower number of subepicardial mesenchymal cells. In addition, the fibronectin aggregation in their subepicardium is abnormal (Jenkins et al., 2005

The mesenchymal cells (deriving from the epicardial cells) are able to migratefrom the epicardium to the subendocardial area where they differentiate into fibroblasts, which synthesize extracellular matrix. These mesenchymal cells migrate to the subendocardial area where they form heart valves. They also play an active role in the formation of the fibrous heart skeleton by inducing cardiomyocyte-fibroblast transformation, which occurs in areas of insulation of atrial and ventricular myocardium (Winter, Gittenberger-de Groot 2007).

The recent studies on chicken embryos, indicate an inductive influence of EPDC on those cardiac myocytes that differentiate into the conductive system of the heart (Gittenberger-de Groot et al., 2003) and the periarterial and subendocardial Purkinje fibers (Gourdie et al., 1998,1999). EPDC are also able to differentiate into smooth muscle cells of the tunica media and fibroblasts of the adventitia (Vrancken Peeters et al., 1999). This suggests that the inductive influence of EPDC on Purkinje fiber differentiation is indirect and does not require a direct contact with the arteries and periarterial Purkinje fibers. In vitro studies demonstrated that endothelin cascade induces Purkinje fiber differentiation (Gourdie et al., 1998). This has been confirmed by in vivo studies
(Takebayashi-Suzuki et al., 2000), which showed that the communication between EPDC and primitive cardiocytes is mediated via endothelins released from EPDC. However, in birds, the EPDC play a more direct role in differentiation of periarterial and subendocardial Purkinje fibers of the heart.

In some rare cases the epicardial mesothelium undergoes a malignant transformation into a tumor - mesothelioma. It is a very rare tumor, which derives from membranous serosa of body cavities, and rarely from pericardium or from the epicardium (Hammar 2006). In the latter case, the tumor grows into the pericardial cavity and surrounds the heart. Microscopically, this tumor consists of epithelial cells, which sometimes form canalicular, glandular or papillomatous structures.

\section{Acknowledgments}

This paper is supported by Ministry of Education and Science grant (\#2P05A 11128) and internal funds of the Medical University of Warsaw. The technical help of A. Podbielska and M. Michniewska is much appreciated.

\section{References}

BERNANKE, D.H., VELKEY, J.M. (2002) Development of the coronary blood supply: changing concepts and current ideas. Anat Rec (New Anat) 269: 198208.

BLAND, E.F., WHITE, P.D., and GARLAND, J. (1933) Congenital anomalies of coronary arteries: report of an unusual case associated with cardiac hypertrophy. Am Heart J8: 787-801.

BOGERS, A.J.J.C., GITTENBERGER DE GROOT, A.C., POELMANN, R.E., PEAULT, B.M. and HUYSMANS, H.A. (1989) Development of the origin of the coronary arteries, a matter of ingrowth or outgrowth? Anat Embryo/180: 437441.

CANO, A., PÉREZ-MORENO, M., RODRIGO, I., LOCASCIO, A., BLANCO, M.J., DEL BARRIO, M.G., PORTILLO, F. and NIETO, M.A. (2000) The transcription factor snail controls epithelial-mesenchymal transitions by repressiong $E$ cadherin expression. Nature Cell Bio/2: 76-83.

CARMONA, R., GONZÁLEZ-IRIARTE, M., MACÍAS, D., PÉREZ-POMARES, J.M., GARCÍA-GARRIDO, L., MUÑOZ-CHÁPULI, R. (2000) Immunolocalization of the transcription factor Slug in the developing avian heart. Anat Embryol201: 103-109.

CONTE, G., PELLEGRINI, A. (1984) On the development of the coronary arteries in human embryos, stages 14-19. Anat Embryol169: 209-218.

COX, C.M., POOLE, T.J. (2000) Angioblasts differentiation is influenced by the local invironment: FGF-2 induces angioblasts and patterns vessel formation in the quail embryo. Dev Dyn 218: 371-382.

DETTMAN, R.W., DENETCLAW, W., ORDAHL, C.P. and BRISTOW, J. (1998) Common epicardial origin of coronary vascular smooth muscle, perivascular fibroblasts, and intermyocardial fibroblasts in the avian heart. Dev Bio/193: 169181.

DRAKE, C.J., BRANDT, S.J., TRUSK, T.C. and LITTLE, C.D. (1997) TAL1/SCL is expressed in endothelial progenitor cells/angioblassts and defines a dorsal-toventral gradient of vasculogenesis. Dev Biol192: 17-30.

GITTENBERGER-DE GROOT, A.C., VRANCKEN PEETERS, M.P.F.M., MENTINK, M.M.T., GOURDIE, R.G. and POELMANN, R.E. (1998) Epicardium-derived cells contribute a novel population to the myocardial wall and the atrioventricular cushions. Circ Res 82: 1043-1052.

GITTENBERGER-DE GROOT, A.C., BLOM, N.M., AOYAMA, N., SUCOV, H., WENINK, A.C.G. and POELMANN, R.E. (2003) The role of neural crest and epicardium-derived cells in conduction system formation. Novartis Foundation Symposium 250: 125-141.

GONZÁLEZ-IRIARTE, M., CARMONA, R., PÉREZ-POMARES, J.M., MACÍAS, D., COSTELL, M. and MUÑOZ-CHÁPULI, R. (2003) Development of the coronary arteries in murine model of transposition of the great arteries. JMo/ Cel/ Cardiol 35: 795-802. 
GOURDIE, R.G., WEI, Y., KIM, D., KLATT, S.C. and MIKAWA, T. (1998) Endothelininduced conversion of embryonic heart muscle cells into impulse-conducting Purkinje fibers. Proc Natl Acad Sci USA 95: 6815-6818.

GOURDIE, R.G., KUBALAK, S.W. and MIKAWA, T. (1999) Conduction the embryonic heart: orchestrating development of specialized cardiac tissue. Trends Cardiovasc Med 9: 18-26.

GUADIX, J., CARMONA, R., MUÑOZ-CHÁPULI, R. and PÉREZ-POMARES, J.M. (2006) In vivo and in vitro analysis of the vasculogenic potential of avian proepicardial and epicardial cells. Dev Dyn 235: 1014-1026.

HAMBURGER, V., HAMILTON, H.L. (1951) A series of normal stages in the development of the chick embryos. JMorpho/88: 49-92.

HAMMAR S.P. (2006) Macroscopic, histologic, histochemical, immunohistochemical, and ultrastructural features of mesothelioma. Ultrastruct Patho/30: 3-17.

HANNAN, R.L., KOUREMBANAS, S., FLANDERS, K.C., ROGELJ, S.J., ROBERTS, A.B., FALLER, D.V. and KLAGSBRUN, M. (1988) Endothelial cells synthetize basic fibroblast growth factor and transforming growth factor beta. Growth Factors 1: 7-17

HATCHER, C.J., DIMAN, NYS-G, KIM, M.-S., PENNISI, D., SONG, Y., GOLDSTEIN, M.M., MIKAWA, T. and BASSON, C.T. (2004) A role for Tbx5 in proepicardial cell migration during cardiogenesis. Physiol Genomics 18: 129-140.

HEINZBERGER, C.F.M. (1983) Development of myocardial vascularization in the rat. Acta Morphol Neerl-Scand21: 267-284.

HIRAKOW, R. (1983) Development of the cardiac blood vessels in staged human embryos. Acta Anat 115: 220-230.

HIRUMA, T., HIRAKOW, R. (1989) Epicardial formation in embryonic chick heart: computer-aided reconstruction, scanning, and transmission electron microscopic stidies. Am J Anat 184: 129-138.

HOOD, L.C., ROSENQUIST, T.H. (1992) Coronary artery development in the chick: origin and deployment of smooth muscle cells, and the effects of neural cell ablation. Anat Rec 234: 291-300.

HUNGERFORD, J.E., LITTLE, C.D. (1999) Developmental biology of the vascular smooth muscle cell: building a multilayered vessel wall. J Vasc Res 36:2-27.

HUTCHINS, G.M, KESSLER-HANNA, A. and MOORE, G.W. (1988) Development of the coronary arteries in the embryonic human heart. Circulation 77: 12501257.

HO, E., SHIMADA, Y. (1978) Formation of the epicardium studied with the scanning electron microscope. Dev Bio/66: 579-585.

JENKINS, S.J., HUTSON, D.R. and KUBALAK, S.W. (2005) Analysis of the proepicardium-epicardium transition during the malformation of the RXRalpha/- epicardium. Dev Dyn 233: 1091-1101.

JOSEPH-SILVERSTEIN, J., RIFKIN, D.B. (1987) Endothelial cell growth factors and the vessel wall. Semin Thromb Hemostasis 13: 504-513.

KÁLMÁN, F., VIRÁGH, S. and MODIS, L. (1995) Cell surface glycoconjugates and the extracellular matrix of the developing mouse embryo epicardium. Anat Embryol191: 451-464.

KATTAN, J., DETTMAN, R.W. and BRISTOW, J. (2004) Formation and remodeling of the coronary vascular bed in the embryonic avian heart. Dev Dyn230: 34-43.

KUHN, H.-J., LIEBHERR, G. (1988) The early development of the epicardium in Tupaia belangeri. Anat Embryol 177: 225-234.

KURKIEWICZ, T. (1909) O histogenezie mieSnia sercowego zwierzat kregowych. Bull Int Acad Sci Cracovie, 148-191.

KWEE, L., BALDWIN, H.S., SHEN, H.M., STEWART, C.L., BUCK, C., BUCK, C.A. and LABOW, M.A. (1995) Defective development of of the embryonic and extraembryonic circulatory systems in vascular cell adhesion molecule (VCAM1) - deficient mice. Development 121: 489-503.

MARKWALD, R.R., FITZHARRIS, T.P. and MANASEK, F.J. (1977) Structural development of endocardial cushions. Am J Anatomy 148: 85-119.

MANDARIM-DE-LACERDA, C.A. (1990) Development of the coronary arteries in staged human embryos (The Paris Embryological Collection Revisited) Ann Acad Bras Ci62:79-84.

MÄNNER, J. (1992) The development of the pericardial villi in in the chick embryo. Anat Embryol 186: 379-385.

MÄNNER, J. (1993) Experimental study on the formation of the epicardium in chick embryos. Anat Embryol187: 281-289.
MÄNNER, J. (1999) Does the subepicardial mesenchyme contribute myocardioblasts to the chick embryo heart? A quail-chick chimera study tracing the fate of the epicardial primordium. Anat Rec 255: 212-226.

MÄNNER, J., PÉREZ-POMARES, J.M., MACÍAS, S.D. and MUÑOZ-CHÁPULI, R. (2001) The origin, formation and developmental significance of the epicardium: a review. Cell Tissue Organs 169: 89-103.

MÄNNER, J., SCHLUETER, J., BRAND, T. (2005) Experimental analyses of the function of the proepicardium using a new microsurgical procedure to induce loss-of-proepicardial-function in chick embryos. Dev Dyn 233: 1454-1463.

MIKAWA, T., FISCHMAN, D.A. (1992) Retroviral analysis of cardiac morphogenesis: discontinous formation of coronary vessels. Proc Nat/ Acad Sci USA 89: 9504-9508.

MIKAWA, T., GOURDIE, R.G. (1996) Pericardial mesoderm generates a population of coronary smooth muscle cells migrating into the heart along with ingrowth of the epicardial organ. Dev Bio/174: 221-232.

MOORE, A.W., MCINNES, L., KREIDBERG, J., HASTIE, N.D. and SCHEDL, A. (1999) YAC complementation shows a requirement for WT1 in development of epicardium, adrenal gland and throughout nephrogenesis. Development 126: 1845-1857.

MUÑOZ-CHÁPULI, R., GONZÁLEZ-IRIARTE, M., CARMONA, R., ATENCIA, G., MACÍAS, D. and PÉREZ-POMARES, J.M. (2002) Cellular precursors of the coronary arteries. Tex Heart Inst J29: 243-249.

MUÑOZ-CHÁPULI, R., MACÍAS, D., RAMOS, C., GALLEGO, A. and ANDRÉS, V. (1996) Development of the subepicardial mesenchyme and the early cardiac vessels in the dogfish (Scyliorhinus canicula). J Exp Zoo/275: 95-111.

MUÑOZ-CHÁPULI, R., PÉREZ-POMARES, J.M., MACÍAS, D., GARCÍA-GARRIDO, L., CARMONA, R. and GONZÁLEZ, M. (1999) Differentiation of hemangioblasts from embryonic mesothelial cells? A model of the origin of the vertebrate cardiovascular system. Differentiation 64: 133-141.

NAHIRNEY, P.C., MIKAWA, T. and FISCHMAN, D.A. (2003) Evidence for an extracellular matrix bridge quiding proepicardial cell migration to the myocardium of chick embryos. Dev Dyn 227: 511-523.

NESBITT, T., LEMLEY, A., DAVIS, J., YOST, M.J., GOODWIN, R.L. and POTTS, J.D. (2006) Epicardial development in the rat: a new perspective. Microsc Microana/12: 390-398.

OLIVEY, H.E., MUNDELL, N.A., AUSTIN, A.F. and BARNETT, J.V. (2006) Transforming growth factor-beta stimulates epithelial-mesenchymal transformation in the proepicardium. Dev Dyn 235: 50-59.

OWENS, G.K. (1995) Regulation of differentiation of vascular smooth muscle cells. Physiol Rev 75: 487-517.

PARDANAUD, L., YASSINE, F. and DIETERLEN-LIEVRE, F. (1989) Relationship between vasculogenesis, angiogenesis nad haemopoiesis during avian ontogeny. Development 105: 473-485.

PÉREZ-POMARES, J.M., MACÍAS, D., GARCÍA-GARRIDO, L. and MUÑOZCHÁPULI, R. (1998) The origin of the subepicardial mesenchyme in the avian embryo: an immunohistochemical and quail-chimera study. Dev Bio/200: 5768.

PÉREZ-POMARES, J.M., CARMONA, R., GONZALEZ-IRIARTE, M., ATENCIA, G., WESSELS, A. and MUÑOZ-CHÁPULI, R. (2002a) Origin of coronary endothelial cells from epicardial mesothelium in avian embryos. Int J Dev Biol 46: 1005-1013.

PÉREZ-POMARES, J.M., MIRONOV, V., GUADIX, J.A., MACÍAS, D., MARKWALD, R.R., MUÑOZ-CHÁPULI, R. (2006) In vitro self-assembly of proepicardial cell aggregates: an embryonic vasculogenic model for vascular tissue engineering. Anat Rec Part A288A: 700-713.

PÉREZ-POMARES, J.M., PHELPS, A., SEDMEROVA, M., CARMONA, R., GONZALEZ-IRIARTE, M., MUÑOZ-CHÁPULI, R. and WESSELS, A. (2002b) Experimental studies on the spatiotemporal expression of WT1 and RALDH2 in the embryonic avian heart: a model for the regulation of myocardial and valvuloseptal development by epicardially derived cells (EPDCs). Dev Bio/247: 307-326.

POElmanN, R.E., GITtenBERgeR-DE GROOT, A.C., MENTINK, M.M.T., BOKENKAMP, R. and HOGERS, B. (1993) Development of the cardiac coronary vescular endothelium, studied with antiendothelial antibodies, in chickenquail chimeras. Circ Res 73: 559-568.

POELMANN, R.E., LIE-VENEMA, H., GITTENBERGER-DE GROOT, A.C. (2002) 
The role of the epicardium and neural crest as extracardiac contributors to coronary vascular development. Texas Heart Inst J29: 255-261.

POOLE, T.J., FINKELSTEIN, E.B. and COX, C.M. (2001) The role of FGF and VEGF in angioblasts induction and migration during vascular development. Dev Dyn 220: 1-17.

RATAJSKA, A., CISZEK, B. and SOWINSKA, A. (2003) Embryonic development of coronary vasculature in rats: corrosion casting studies. Anat Rec270A(2): 109116.

RATAJSKA, A., FIEJKA, E. (1999) Prenatal development of coronary arteries in the rat: morphologic pattern. Anat Embryo/200: 533-540.

RATAJSKA, A., CZARNOWSKA, E., KOLODZINSKA, A., KLUZEK, W. and LESNIAK, W. (2006) Vasculogenesis of the embryonic heart: origin of bloodisland-like structures. Anat Rec $A$ 288: 223-232.

RATAJSKA, A., TORRY, R.T., KITTEN, G.T., KOLKER, S.J. and TOMANEK, R.J. (1995) Modulation of cell migration and vessel formation by vascular endothelial growth factor and basic fibroblast growth factor in cultured embryonic heart. Dev Dyn 203: 399-407.

RATAJSKA, A., ZLOTOROWICZ, R., BLAZEJCZYK, M. and WASIUTYNSKI, A. (2005) Coronary artery embryogenesis in cardiac defects induced by retinoic acid in mice. Birth Defects Res A Clin Mol Terato/73: 966-979.

RATAJSKA, A., ZARSKA, M., QUENSEL, C. and KRÄMER, J. (2001) Differentiation of the smooth muscle cell phenotypes during embryonic development of coronary vessels in the rat. Histochem Cell Bio/116: 79-87.

RONGISH, B.J., TORRY, R.J., TUCKER, D.C. and TOMANEK, R.J. (1994) Neovascularization of embryonic rat hearts cultured in oculo closely mimics in utero coronary vessel development. J Vasc Res 31: 205-21.

RYCHTER, Z., JIRÁSEK, J.E., RYCHTEROVÁ, V. and UHER, J. (1975) Vascularization of heart in human embryo: location and shape of non-vascularized part of cardiac wall. Folia Morphol (Prague) 23: 88-96.

SCHLUETER, J., MÄNNER, J. and BRAND, T. (2006) BMP is important regulator of proepicardial identity in the chick embryo. Dev Bio/295: 546-558.

SCHULTE, I., SCHLUETER, J., ABU-ISSA, R., BRAND, T. and MÄNNER, J. (2007) Morphological and molecular left-right asymmetries in the development of the proepicardium: a comparative analysis on mouse and chick embryos. Dev Dyn 236: 684-95

STERPETTI, A.V., CUCINA, A., D'ANGELO, L.S., CARDILLO, B., CAVALLARO, A. (1993) Shear stress modulates the proliferation rate, protein synthesis, and mitogenic activity of arterial smooth muscle cells. Surgery 113: 691-699.

TAKEBAYASHI-SUZUKI, K., YANAGISAWA, M., GOURDIE, R.G., KANZAWA, N. and MIKAWA, T. (2000) In vivo induction of cardiac Purkinje fiber differentiation by coexpression of preproendothelin-1 and endothelin converting enzyme-1. Development 127: 3523-3532.

TOMANEK, R.J (2005) Formation of coronary vasculature during develoopment. Angiogenesis 8: 273-284.

TOMANEK, R.J., ISHII, Y., HOLIFIELD, J.S., SJOGREN, C.L., HANSEN, H.K. and MIKAWA, T. (2006a) VEGF family mambers regulate myocardial tubulogenesis and coronary artery formation in the embryo. Circ Res 98: 947-953.

TOMANEK, R.J., HANSEN, H.K. and DEDKOV, E.I. (2006b) Vascular patterning of the quail coronary system during development. Anat Rec 288A: 989-999.

TOMANEK, R.J., HU, N., PHAN, B. and CLARK, E.D. (1999b) Rate of coronary vascularization during embryonic chicken develoopment is influenced by the rate of myocardial growth. Cardiovasc Res 41: 663-671.

TOMANEK, R.J., HOLIFIELD, J.S., REITER, R.S., SANDRA, A. and LIN, J.J. (2002) Role of VEGF family mambers and receptors in coronary vessel formation. Dev Dyn 225:233-240.
TOMANEK, R.J., LOTUN, K., CLARK, E.B., SUVARNA, P.R., HU, N. (1998) VEGF and bFGF stimulate myocardial vascularization in embryonic chick. $A m J$ Physio/274: H1620-1626.

TOMANEK, R.J., RATAJSKA, A., KITTEN, G.T., YUE, X. and SANDRA, A. (1999a) Vascular endothelial growth factor expression coincides with coronary vasculogenesis and angiogenesis. Dev Dyn 215: 54-61.

TOMANEK, R.J., ZHENG, W. (2002) Role of growth factors in coronary morphogenesis. Tex Heart Inst J 29:250-254.

TOMANEK, R.J., ZHENG, W., PETERS, K.G., LIN, P., HOLIFIELD, J.S. and SUVARNA, P.R. (2001) Multiple growth factors regulate coronary embryonic vasculogenesis. Dev Dyn 221: 265-273.

VAN DEN EIJNDE, S.M., WENINK, A.C., VERMEIJ-KEERS, C. (1995) Origin of subepicardial cells in rat embryos. Anat Rec 242: 96-102.

VIRÁGH, S., CHALLICE, C.E. (1981) The origin of the epicardium and the embryonic myocardial circulation in the mouse. Anat Rec 201: 157-168.

VIRÁGH, S., GITTENBERGER-DE GROOT, A., POELMANN, R.E. and KÁLMÁN, F. (1993) Early development of quail heart epicardium amd associated vascular and glandular structures. Anat Embryo/188: 381-393.

VIRÁGH, S., KÁLMÁN, F., GITTENBERGER-DE GROOT, A.C., POELMANN, R.E. and MOORMAN, A.F.M. (1990) Angiogenesis and hematopoiesis in the epicardium of the vertebrate embryo heart, w: "Embryonic origins of defective hear development", Bockman DE, Kirby ML (wyd). Ann NY Acad Sci USA 588: 455458

VERBERNE, M.E., GITTENBERGER-DE GROOT, A.C., POELMANN, R.E. (1998) Lineage and development of the parasympathetic nervous system of the embryonic chick heart. Anat Embryol 198: 171-184.

VRANCKEN PEETERS, M.P.F.M., MENTINK, M.M.T., POELMANN, R.E., GITTENBERGER-DE GROOT, A.C. (1995) Cytokeratins as a marker for epicardial formation in the quail embryo. Anat Embryo/191: 503-508.

VRANCKEN PEETERS, M.P.F.M., GITTENBERGER-DE GROOT, A.C., MENTINK, M.M.T., HUNGERFORD, J.E., LITTLE, C.D. and POELMANN, R.E. (1997a) Differences in development of coronary arteries and veins. Cardiovasc Res 36 101-110.

VRANCKEN PEETERS, M.P.F.M., GITTENBERGER-DE GROOT, A.C., MENTINK, M.M.T., HUNGERFORD, J.E., LITTLE, C.D. and POELMANN, R.E. (1997b) The development of the coronary vessels and their differentiation into arteries and veins in the embryonic quail heart. Dev Dyn 208: 338-348.

VRANCKEN PEETERS, M.P.F.M., GITTENBERGER-DE GROOT, A.C., MENTINK, M.M.P. and POELMANN, R.E. (1999) Smooth muscle cells and fibroblasts of the coronary arteries derive from epithelial-mesenchymal transformation of the epicardium. Anat Embryo/199: 367-378.

WALDO, K.L., KUMINSKI, D.H., KIRBY, M.L. (1994) Association of the cardiac neural crest with development of the coronary arteries in the chick embryo. Anat Rec 239: 315-331.

WALDO, K.L., WILLNER, W. and KIRBY, M.L. (1990) Origin of the proximal coronary artery stems and a review of ventricular vascularization in the chick embryo. Am J Anat 188: 109-120.

WATT, A.J., BATTLE, M.A., DUNCAN, S.A. (2004) GATA4 is essential for formation of the proepicardium and regulates cardiogenesis. ProcNat/AcadSci USA 101 12573-12578.

WESSELS, A., PÉREZ-POMARES, J.M. (2004) The epicardium and epicardially derived cells (EPDCs) as cardiac stem cells. Anat Rec 276:43-57.

WINTER, E.M., GITTENBERGER-DE GROOT, A.C. (2007) Epicardium-derived cells in cardiogenesis and cardiac regeneration. Cell Mol Life Sci64: 692-703. 
Related, previously published Int. J. Dev. Biol. articles

See our recent Special Issue Developmental Biology in Poland edited by Kloc, Maleszewski and Tarkowski at: http://www.ijdb.ehu.es/web/contents.php?vol=52\&issue=2-3

See our Special Issue Mammalian Reproduction \& Development in honor of Anne McLaren and edited by Brigid Hogan at: http://www.ijdb.ehu.es/web/contents.php?vol=45\&issue=3

An efficient method for isolation of murine bone marrow mesenchymal stem cells Samad Nadri, Masoud Soleimani, Reza H. HosSeni, Mohammad Massumi, Amir Atashi and Reza Izadpanah Int. J. Dev. Biol. (2007) 51: 723-729

Enhanced development of porcine embryos cloned from bone marrow mesenchymal stem cells Hai-Feng Jin, B. Mohana Kumar, Jung-Gon Kim, Hye-Jin Song, Yeon-Ji Jeong, Seong-Keun Cho, Sivasankaran Balasubramanian, Sang-Yong Choe and Gyu-Jin Rho

Int. J. Dev. Biol. (2007) 51: 85-90

Interleukin-2 induces the proliferation of mouse primordial germ cells in vitro

Cristina Eguizabal, Maria D. Boyano, Alejandro Díez-Torre, Ricardo Andrade, Noelia Andollo, Massimo De Felici and Juan Aréchaga

Int. J. Dev. Biol. (2007) 51: 731-738

Tracing the hemangioblast during embryogenesis: developmental relationships between endothelial and hematopoietic cells Thierry Jaffredo, Karine Bollerot, Daisuke Sugiyama, Rodolphe Gautier and Cécile Drevon

Int. J. Dev. Biol. (2005) 49: 269-277

Of birds and mice: hematopoietic stem cell development Isabelle Godin and Ana Cumano

Int. J. Dev. Biol. (2005) 49: 251-257

Embryonic development of the human hematopoietic system Manuela Tavian and Bruno Péault

Int. J. Dev. Biol. (2005) 49: 243-250

Vasculogenesis and angiogenesis in the mouse embryo studied using quail/mouse chimeras

Michel Pudliszewski and Luc Pardanaud

Int. J. Dev. Biol. (2005) 49: 355-361

Developmental expression of Pod 1 in Xenopus laevis Subreena Simrick, Karine Massé and Elizabeth A. Jones Int. J. Dev. Biol. (2005) 49: 59-63

Origin of coronary endothelial cells from epicardial mesothelium in avian embryos.

José-María Pérez-Pomares, Rita Carmona, Mauricio González-Iriarte, Gerardo Atencia, Andy Wessels and Ramón Muñoz-Chápuli Int. J. Dev. Biol. (2002) 46: 1005-1013

The contribution of the proepicardium to avian cardiovascular development

JM Perez-Pomares, A Phelps, R Munoz-Chapuli, A Wessels

Int. J. Dev. Biol. (2001) 45: S155-S156

Origin of endothelial cells from mesothelial-derived mesenchymal cells in the liver of avian embryos

R Munoz-Chapuli, R Carmona, M Gonzalez-Iriarte, JM Perez-Pomares, D Macias, G Atencia, MJ Aranda

Int. J. Dev. Biol. (2001) 45: S143-S144

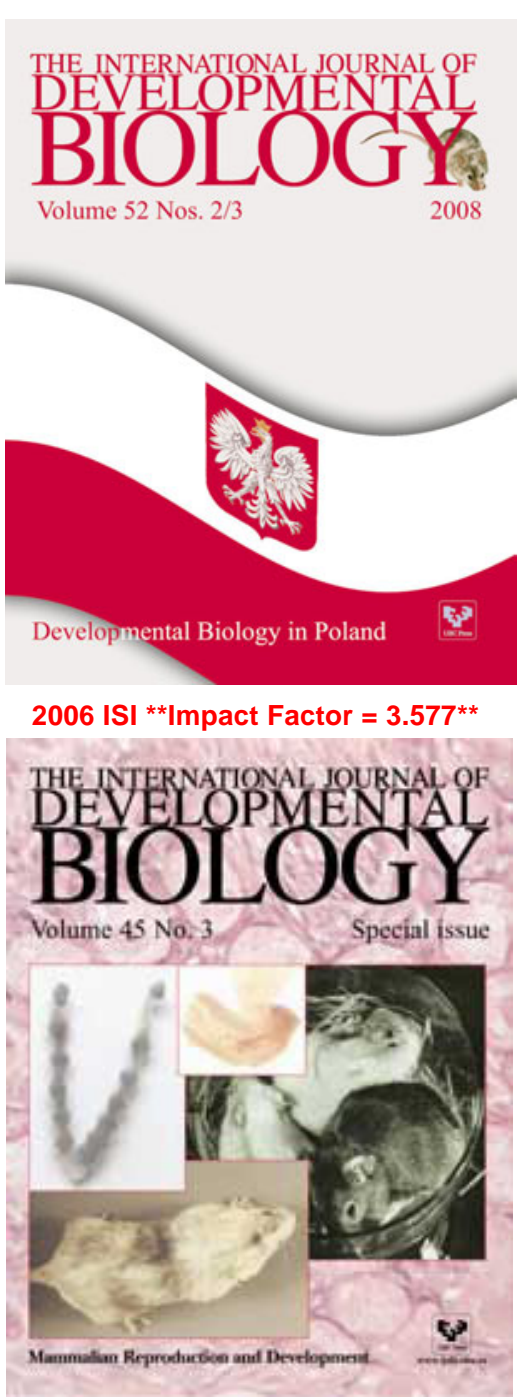

